\title{
The contribution of work engagement over proactive personality and proactive work behavior
}

\author{
Diana-Felicia Marica
}

University of Bucharest, Department of Psychology

\section{ARTICLE INFO}

Article history:

Received 18-July-2018

Accepted 20-August-2018

Available online 15-September-2018

This article should be cited as: Marica, D-F. (2018). The contribution of work engagement over proactive personality and proactive work behavior. Studia Doctoralia. Psychology and Educational Science, 15,106-115.

This is an open access article under the CC BY license (http://creativecommons.org/licenses/by/4.0/).

Corresponding author at: University of Bucharest, Department of Psychology, 90 Panduri Av, Bucharest, RO.

E-mail address: felicia.marica@gmail.com

\section{ABSTRACT}

The purpose of this study was to investigate the incremental validity of work engagement over the proactive personality in predicting proactive behavior at work. Thus, it was tested the extent to which work engagement with its dimensions - dedication, absorption, vigor - can predict the proactive behavior at the workplace over the proactive personality. The data was collected through an online questionnaire and the application was made on a sample of 120 participants who were currently working in an organization, student association, or nongovernamental organization. The results of the research have shown that work engagement is a predictor of the criterion in the incremental validity model, although, only absorption of all three dimensions has proved to be a statistically significant unic predictor. Theoretical and practical implication will be discussed.

Keywords: work engagement, proactive personality, proactive work behavior

\section{INTRODUCTION}

Current changes in organizations and work processes require a reconsideration of a traditional perspective on the performance of the individual at work (Ilgen \& Pulakos, 1999). Today's workplaces are typically characterized by rapid restructuring that includes the emergence of innovations and new technologies, many of the employees working in companies with decentralized management (Balogun \& Johnson, 2004). For good performance, employees are more required than ever to do things on their own initiative, not just to meet the objectives proposed 
by the organization (Frese \& Fay, 2001). An active attempt to self-interest or the environment to bring a different future, that is, to be proactive, is an increasingly vital way to behave in contemporary jobs (Ohly \& Fritz, 2007).

More attention is paid to positive psychology, which aims at studying human power, optimal functioning and positive subjective experiences (Schaufeli \& Bakker, 2004). The recent tendency to focus on optimal functionality has also brought special attention to organizational psychology, which defines this approach to organizational behavior as a positive study focusing on the potential of human resources and psychological capabilities that can be measured, developed and managed by effectively improving performance in today's workplace (Schaufeli \& Bakker, 2004). If organizations believe that employees are the most valuable investment, it proves not only their interest in their performance - promoted by human resources management - but also in physical and psychological health - promoted by occupational psychology (Vârgă, Zaborilă, Sulea, \& Măricuţoiu , 2009).

Present era requires rapid change and that there is a high demand for innovation amongst employees, proactive behavior at work is increasingly a necessity for the optimal functioning of organizations. Thus, the usefulness of the present study can be expressed in two considerations. Firstly, the present study aims to contribute to the literature through its outcomes, which aim at updating and clarifying the level of knowledge on the proactive behavior construct at the workplace. Second, the study aims to clarify how proactive behavior at work can be explained by antecedent variables, such as work ngagement over proactive personality.

\section{Proactive Personality and Proactive Behavior}

In the last decades, researchers have recognized that individuals are rarely passive or reactive to the context in which they are part (Parker, Bindl, \& Strauss, 2010; Strauss \& Parker, 2014); they are forming their own role within an organization, career, work environment, social and organizational context. Proactive behaviors are labeled in the literature as forward-looking, self-activating, persistent and desirable self-activating behaviors (Belschak \& Den Hartog, 2012) and the need for it is suggested by the considerable increase in concepts that belong to proactivity at work (Crant, 2000).

Due to the growing importance of proactive behaviors in the workplace in recent years, researchers have focused on how they can engage employees in proactive behavior, precisely to promote creativity, innovation, change. Thus, reasearchers tried to understand the contextual and individual antecedents, the way in which proactivity is trained and cultivated, as well as the results that arise at both organizational and individual level (Crant, 2000; Grant \& Ashford, 2008).

Individual antecedents variables in this context refer to a set of individual differences that allow the employee to have the potential to manifest proactive behaviors; Here are included: age, gender, knowledge, abilities, goal orientation, proactive personality, the five personality factors, self-efficacy, positive status (Crant, 2000; Parker, Bindl \& Strauss, 2010; Wu \& Parker, 2011).

Personality traits, especially those that reflect the desire to change, tend to lead increasingly to the success of individuals and the competitive advantage of their organizations (Fugate, Kinicki, \& Ashforth, 2004; Seibert, Crant \& Kraimer, 1999). In general, personality is considered to influence the success of professional life for two reasons: (1) Careers are the product of trends and (2) Professional life is full of weak situations where personality plays a dominant role in choosing behavior (Seibert, Krant, \& Kraimer, 1999).

In their study, Parker and Collins (2010), summarized the previous variables that have been associated as predictors of proactive behavior in the workplace, including proactive personality (Parker et al., 2006; Seibert, Kraimer \& Crant, 2001), immediate consequences and future consequences of actions (Strathman, Gleicher, Boninger, \& Edwards, 1994), goal-oriented learning (Dweck, 1986), consistency (Roberts, Chernysheako, Stark, \& Goldberg, 2005), selfesteem and responsibility (Parker \& Collins, 2010), goaloriented performance (Parker \& Collins, 2010). Although several individual antecedents have been proposed, proactive personality is the most relevant one (Parker, Williams, \& Turner, 2006) and has been considered a predictor for proactive behaviors in the workplace (Becherer \& Maurer, 1999).

The proactive personality construct has its origins in interactionism, which states that situations are largely a function of the person and the person's behavior is a function of the situation; And in the cognitive-social theory (Bandura, 1986), which claims that the person, the environment and the behavior constantly influence each other. Proactive people are characterized by looking for opportunities, showing the initiative and trying to bring about a meaningful change (Bateman \& Crant, 1993). Proactive personality is conceptualized as a strong propensity to engage in proactive behaviors in various situations and contexts (Bateman \& Crant, 1993) and is considered to be a stable mood to take initiative in a wide range of situations and activities (Seibert, Kraimer \& Crant, 2001). Prototype of proactive personality has been characterized as a relatively unconstrained person and has 
an effect on environmental change (Bateman \& Crant, 1993).

Empirical evidence demonstrates that proactive personality is a one-dimensional construct that is positively correlated with a large number of organizational variables such as entrepreneurial intentions (Crant, 1996), career success (Seibert, Crant, \& Kraimer, 1999), performance at work (Thompson, 2005), organizational behavior, satisfaction of life and work (Greguras \& Diefendorff, 2010). At the same time, this is considered the individual trait that leads to proactive behavior (Searle, 2011), a predictor of problem solving in a proactive way (Parker et al., 2006) and individual innovation (Seibert et al., 2001).

An explanation for which proactive personality is positively related to career success lies in the fact that people with proactive personalities are likely to engage in proactive behavior (Seibert et al., 2001). At the same time, empirical studies support this assertion as proactive personality is a stable mood to take a personal initiative in a wide range of activities and situations (Seibert et al., 2001) and that proactive behavior implies an initiative to improve the circumstances current or in the creation of new ones (Crant, 2000). Therefore, people with proactive attitudes adopt proactive behavior in their environment (Fuller \& Marler, 2009).

Previous studies have established the relationship between proactive personality and proactive behaviors at work, in its dimensions, voice, control, individual innovation and problem prevention (Griffin, Neal, \& Parker, 2007; Parker \& Collins, 2010; Searle, 2011). These four types of proactive behavior share a positive change in organizations and are considered latent factors of proactive behavior at work (Searle, 2011). In the study of Fuller and Marler (2009) proactive personality was positively correlated with taking charge and voice behavior - both behaviors that indicate leadership potential and make it more likely to see employees in the organization.

From the perspective of career success, proactive behavior facilitates greater performance and generates social capital (eg, social networking), and some forms of proactive behavior such as voice behavior, taking charge, innovation can also help to achieve the potential management (Fuller, Barnett, Hester, Relyea and Frey, 2007). It is believed that people with proactive personality engage in career development activities, at least partly because of the need to achieve (Thompson, 2005) and motivation to learn (Major, Turner, \& Fletcher, 2006). Therefore, according to Fuller et al. (2012), individuals with high levels of proactive personality would expect to engage in taking charge behaviors and demonstrate a larger career initiative than individuals with low levels of proactivity. People who are likely to take the initiative do this frequently, offering suggestions for finding an opportunity or improving a situation; In other words, it is often necessary to articulate ideas in order to bring them to actions (Fuller, Marler, \& Hester, 2012). Therefore, it is possible for proactive individuals to engage in vocal behavior (LePine \& Van Dyne, 1998). Moreover, in the case of proactive individuals, it is very likely to implement their own ideas or suggestions for bringing change, assuming control (Fuller, Marler, \& Hester, 2012).

Studies confirm the consistent positive relationship between proactive personality and distinct proactive behaviors (Bindl \& Parker, 2010). These include building work-related relationships (Lambert, Eby, \& Reeves, 2006), proactive workplace socialization (Kammeyer-Mueller \& Wanberg, 2003), career initiative (Seibert et al., 2001) problems and vocal behavior (Parker \& Collins, 2010).

\section{Work Engagement and Proactive Behavior}

Due to the emergence of organizational positive psychology, it is not surprising that the positive aspects of health and well-being are becoming increasingly popular in Occupational Health Psychology (Schaufeli \& Bakker, 2004). One of these positive aspects is work engagement and the interest in this concept has been manifested and increased in research on labor exhaustion (Maslach, Schaufeli \& Leiter, 2001). Contrary to those who suffers from burnout, work engaged employees have an energyefficient sense of attachment to their work activities and they are seen to be able to handle the requirements of the workplace (Schaufeli \& Bakker, 2004). Because Maslach and Leiter (1997) define burnout in terms of exhaustion, cynicism and reduced professional efficacy, it turns out that work engagement is characterized by energy, commitment and effectiveness (Schaufeli \& Bakker, 2004).

Work engagement is conceptualized as a positive, fulfilling, motivating affective, characterized by vigour, dedication and absorption. This approach takes into account affective, cognitive and behavioral aspects (Schaufeli, Bakker, \& Salanova, 2006). On the other hand, Leiter and Bakker (2010) define work engagement as a motivational concept, which belongs to any job that involves challenges. This describes the ability of employees to solve problems, connect with people and develop service innovation (Leiter \& Bakker, 2010). The basic components of engagement are vigor, dedication and absorption (Schaufeli et al., 2002).

Absorption is characterized by being fully focused and preoccupied with their own work, so that time passes very quickly, and stopping from work is hard to accomplish. (Schaufeli, Bakker, \& Salanova, 2006). Those who have a 
high level of absorption feel that they are usually happy with their work, feel immersed in it and have difficulty detaching themselves. As a consequence, everything around is forgotten and time seems to fly (Schaufeli \& Bakker, 2004). To start proactive behavior and to persist in it needs additional effort (Frese et al., 1997). Thus, in order to perceive opportunities for proactive behavior and to persist in it, it is important that people feel absorbed in their work and focus on it. According to Sonnentag (2003), in order to engage in proactive behavior, it is necessary for individuals to be affectively and cognitively involved in their work and to consider that it deserves to invest an extra effort. In line with the above, the present study proposes the following research hypothesis:

H1: Absorption will predict proactive behavior at work over the proactive personality.

Dedication refers to strong involvement in one's own work, experimentation of enthusiasm, inspiration, pride, challenge and sense of meaning (Schaufeli, Bakker, \& Salanova, 2006). Those who demonstrate high levels of dedication are strongly identified with their work because they feel they are doing something significant, inspirational and provocative. In addition, they usually feel excited and proud of their work (Schaufeli \& Bakker, 2004). When an employee is dedicated to his work, he will most likely engage in proactive actions to maintain and improve the positive aspect of work (Sonnentag, 2003). Accordingly, the present study proposes the second hypothesis of research as:

H2: Dedication will predict proactive behavior at work over the proactive personality.

Vigor is characterized by high levels of energy and resilience during work, by the desire to invest effort in one's

\section{METHODOLOGY}

\section{Participants and procedure}

The participants were 120 adults currently working in organization (56.2\%), a student association (22.3\%) or a non-governmental organization (19.8\%). The sample consisted of 39 males (32.5\%) and 81 women. The age range was 19 to 51 years old $(M=26.40, S D=6.59)$. The sampling method of this study was one of non-probabilistic, convenient. The data was collected through a online questionnaire in January 2018 and May 2010.

\section{Instruments}

Work engagement. The short version of Utrecht Work Engagement (Schaufeli, Bakker, \& Salanova, 2006), adapted in Romanian (Vîrgă, Zaborilă, Sulea, \& Măricuţoiu, own work and persistence even in problematic situations (Schaufeli, Bakker, \& Salanova, 2006). When involved, the person has sufficient resources to consume this extra effort; Feelings like vigor are particularly useful in this case. The individual will be reluctant to consume additional effort when he is insufficiently engaged (Sonnentag, 2003). Because the people engaged feel more vigorous, they can do their job and engage in proactive behaviors. Although there are several different points of view on engaging in work, most researchers agree that the employees with high levels of engagement have also a high level of energy and are strongly identified with their work (Bakker et al., 2008). Therefore, the present study proposes the following research hypothesis:

H3: Vigor will predict proactive behavior at work over the proactive personality.

Regarding the relationship between work engagement and proactive behavior, Sonnentag (2003) analyzed the effect of the daily level of employee engagement on the daily proactive behavior level, focusing in particular on the size of the personal initiative. None of these studies added work engagement as a predictor of proactive behavior with its four dimensions, as outlined in Parker and Collins (2010) study: voice, taking charge, individual innovation and problem prevention. Given this, the proposed study aims to fill this gap in the literature to clarify and complete the list of variables that are associated and can predict proactive behavior at work. This approach is also supported by Searle's meta-analysis (2011), where it is suggested that future study direction should include work engagement as a predictor of proactive behavior at work. In addition, adding work engagement in the prediction relation might increase the predictive power of the proactive personality.

2009), was used to measure the involvement in work. The instrument consists of three subclasses, as follows: Dedication ( 3 items, Cronbach's a $=.86$ ), an exemple of an item is: „At my work, I feel bursting with energy”; Vigour (3 items, Cronbach's a $=.71$ ), an exemple of an item is: „I am enthusiastic about my job"; Absorption (3 items, Cronbach's $a=.68$ ), an exemple of an item is: „I am immersed in my work". In total, it was a 9 items-scale rated on 6-point Likert scale $(0=$ never, up to $6=$ every day $I$ very often).

Proactive personality. Proactive personality was measured with Proactive Personality Scale (Bateman \& Crant, 1993). The psychometric characteristics of the scale are analyzed in Bateman and Crant (1993), which has a good fidelity (Cronbach's $a=.87$ ). Translation was 
performed using the "back-translation" method as described by Hambleton (2005). It was a 17-item scale measured on a 7-point Likert measure from 1 (strong disagreement) to 7 (strong agreement); an example item is: "Wherever I was, I had the force to provoke constructive changes" (Bateman \&Crant , 1993).

Proactive Behavior. Parker and Collins (2010) proposed three categories of proactive behaviors: (a) Proactive work behavior; (b) proactive strategic behaviors and (c) proactive behaviors that target the environment-person (Parker \&Collins, 2010). The present study used only the first category, proactive work behavior which include four facets: taking charge, individual innovation, problem prevention and voice (Parker \& Collins, 2010).

In order to measure level of taking charge were used items proposed by Morrison and Phelps (1999), which were adapted to be self-report rather than supervisor ratings. Four items were selected that presented the highest factor loading and good fidelity (Cronbach's a $=.83$ ); an example item is: "Are you trying to introduce improved procedures at work?" (Parker \& Collins, 2010).

To measure voice behavior, Parker and Collins (2010) selected from Van Dyne and LePine (1998) only those items that were most consistent with the construct definition and which had a good fidelity (Cronbach's $a=$. 75). An example item is: „Do you talk and encourage those at work to get involved in the issues that affect you?"

\section{RESULTS}

For data processing was used SPSS Statistics Version 22 (2013).

Table 1 shows standard deviations and correlations between study variables. Thus, between the proactive personality $(r(118)=.64, p<.01)$ and the proactive work behavior there is a positive correlation, statistically significant, of high intensity. In the case of work engagement's dimensions, Dedication $(r(118)=.47, p$ <.01), Vigor ( $(118)=.43, p<.01)$ and Absorption $(r(118)=$
The measurement of the individual innovation dimension was made with three of the six items proposed by Scott and Bruce (1994) because the other three items were based on the idea of implementation and could overlap with those for the facet taking control (Parker \& Collins, 2010); an example of item is: "Do you generate creative ideas at work?". Factor loading of items was not reported by original authors, so Parker and Collins (2010) only selected items that were focused on generating and promoting innovation and tested their fidelity (Cronbach's a $=.76$ ), as these are the most relevant and distinctive aspects for the individual innovation behavior (Parker \& Collins, 2010).

Problem prevention was assessed with three items that Parker and Collins (2010) developed that focused on achieving continual systems improvement through preventing problems. They tested items fidelity (Cronbach's $a=.75)$. An example of the item is: "Are you trying to find the main cause for things going wrong at work?" (Parker \& Collins, 2010).

All items were cumulated to measure the proactive behavior construct at work. Original versions of the English items were translated into Romanian, then Romanian to English to establish semantic equivalence. It was a 13-item scale (Cronbach's a $=.70$ ), measured on a 5-point Likert measure from 1 (very infrequently) to 5 (very frequently).

$.51, p<.01)$ were correlated positively, statistically significant with proactive work behavior. It was observed that Dedication $(r(118)=.42, p<.01)$, Vigor $(r(118)=.36$, $p<.01)$ and Absorption $(r(118)=.43, p<.01)$ correlates positively, statistically significant with low or average intensity with proactive work behavior. This suggests a degree of independence between the concepts.

Table 1. Descriptive statistics and corelations between the variables

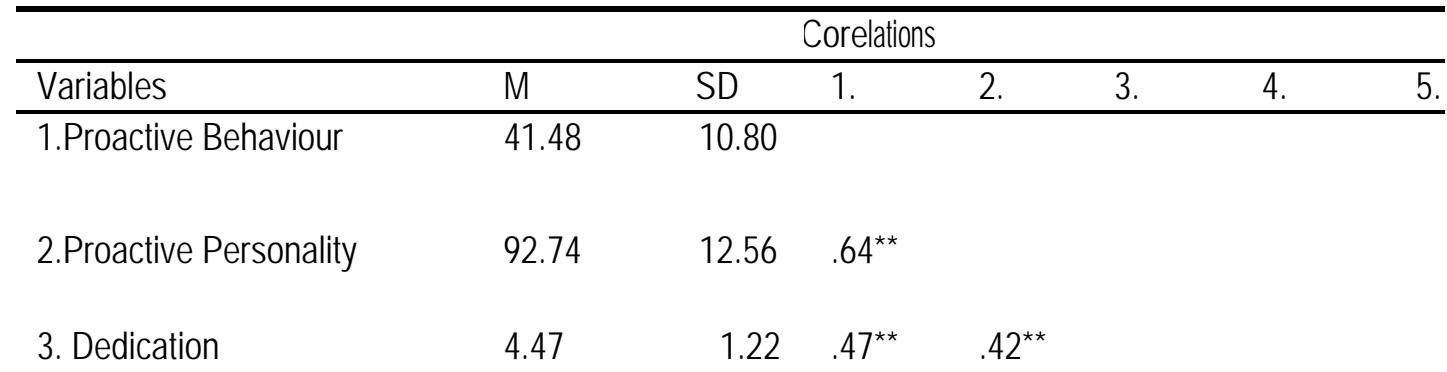



4.Vigour
4.00
$1.13 .43^{\star *}$
$.36^{\star \star}$
$.78^{\star \star}$
5.Absorption
4.38
$1.08 .51^{\star *}$
$.43^{*}$
$.67^{\star \star}$
$.70^{\star \star}$

Note. ${ }^{*} p<.05 ;{ }^{* *} p<.01 ;{ }^{* * *} p \leq .001 ; N=120$

\section{Incremental Validity}

It was examinated the incremental validity of the dimensions of the work engagement, namely dedication, absorption and vigour over the proactive personality in predicting proactive work behavior by using hierarchical regression. An important aspect in examining incremental validity is the order in which variables are integrated into the regression equation model. Following the recommendations of the literature (e.g., Hunsley \& Meyer, 2003), the demographic characteristics were introduced in the first step. Proactive personality was introduced in the second step and in the third step were introduced dedication, vigor, and absorption, as dimensions of work engagement. The results are presented in Table 2.

Table 2. Incremental validity of work engagement dimentions over the proactive personality, age and gender
As reported in Table 2, work engagement score has been able to predict and bring additional variance to the criterion, although it is small $(\Delta R 2=.07, p<.001)$. However, it is worth mentioning that the only dimension that makes a unique and statistically significant contribution in the prediction of proactive work behavior is absorption $(\beta=.21$, $p<.05)$. Thus, hypothesis 1 is supported by results. Dedication does not make a unique, statistically significant contribution to the model $(\beta=.07, p>.05)$. Also, vigour does not make a unique and statistically significant contribution ( $\beta=.05, p>$.05). As a result, hypothesis 2 and 3 are not supported by results.

\section{Proactive behavior}

\begin{tabular}{ll} 
Predictor & $\Delta \mathrm{R}^{2} \quad \mathrm{~B}$ \\
\hline
\end{tabular}

Step 1

.00

Age

Gender

Step 2

$.42^{\star \star \star}$

Proactive Personality

$.65^{\star \star \star}$

Step 3

$.07^{\star \star}$

Dedication

.07

Vigour

.05

Absorption

$.21^{*}$

N

120

Note. $\pitchfork p<.10,{ }^{\star} p<.05,{ }^{* \star} p<.01,{ }^{* \star \star} p<.001$.

\section{DISCUSSION}

The purpose of the study was to investigate the incremental validity of work engagement in predicting proactive work behavior without over proactive personality. Thus, based on the data obtained, it was assessed whether work engagement, consisting of the dimensions of absorption, vigor, and dedication, is a significant predictor of proactive work behavior beyond the proactive personality. Only one of the three dimensions has been 
shown to contribute to the explanation of the dependent variable, although the block of variables belonging to work engagement contributed with $7 \%$ to the model.

With regard to the first hypothesis of the study, it was noted that absorption, as a dimension of work engagement, explains $2.1 \%$ of the variance of the criterion. Thus, the data suggest that when employees have a high level of absorption there is a greater likelihood of them getting involved in proactive behaviors because they feel happy with the work, feel immersed in it and have difficulty detaching from it. This result may be explained by the fact that absorption, as a state of complete concentration and pleasure in one's own work, can be considered, according to Csikszentmihalyi (1990), a consequence of work involvement that occurs when the individual feels energized by work; thins state submits and finds itself in the concept of flux, which implies the tendency towards permanent change. At the same time Warshawsky, Havens and Knafl (2012) study found a positive association between work engagement and proactive work behavior.

Concerning the following two proposed hypotheses of the study, which supported the contribution that dedication and absorption brought to proactive work behavior beyond the proactive personality, it was noticed that they do not bring any statistically significant variation. These results are contrary to the results of Salanova and Schaufeli (2008), which found a correlation between the two facets of work engagement - vigour and dedication - and proactive behaviors. According to the present study, employees who are strongly identified with their work feel enthusiastic, proud of it, have the desire to invest effort in their own work are not more likely to get involved in proactive work behaviors. An explanation of this result could be based on the assumption that there are daily fluctuations of work engagement (Kahn, 1990). In Sonnentag study (2003), at least $40 \%$ of the variance was attributed to personal variation, suggesting that engagement and proactive behavior are not completely stable over time. Moreover, he pointed out that work engagement, apart from the fact that it differs between individuals, it also shows the variation within the person in time, which may show fluctuations from one day to the next (Sonnentag, 2003). The same holds true for proactive behavior: proactive behavior on a given day can be substantially influenced by the general tendency of the individual to show a proactive behavior. This leads to the motivational mechanism of the person of REFERENCES

Barnard, C. I. (1938). The Functions of the Executive. Cambridge, MA: Harvard University Press.

Bateman, T. S., \& Organ, D. W. (1983). Job satisfaction and the good soldier: The relationship between affect and the type "I feel energetic" (Parker, Bindl, \& Strauss, 2010) which provides energy and motivation for engagement in proactive behavior - a mechanism that can not be explored at the full power, since people did not present motivating aspects such as vigor and dedication at work.

These explanations are limited to the present study and can not be valid generalizations or a definitive explanation of how the constructs interact.

Concluding, the study has shown evidence that proactive behavior can be explained by work engagement beyond proactive personality, succeeding in bringing about a further $7 \%$ variation. However, between the dimensions of work engagement, only absorption was a unique, statistically significant predictor for proactive work behavior.

\section{Study Limitations and Future Research}

Firstly, the sample was composed entirely of people from Romania. Although there is no empirical evidence of variation in proactive behavior by culture, it could be a limit to generalize the results. At the same time, the sample was mostly composed of females, which could prevent generalization of the results for the male population.

Secondly, the study did not have enough selected data to reveal the characteristics of the participants that could influence the relationship between the variables studied. Thus, the following variables can be proposed, which could be considered in future studies: the industry in which employees work, the number of hours spent at work, leadership, the relationship with colleagues, conscientiousness.

Thirdly, the questionnaire was distributed and managed online via social networking, which leads to the possibility for participants to fill in randomly or multiple times the questionnaire. At the same time, the groups in which the questionnaire was distributed do not guarantee the variability of the population from which the sample was made.

Fourthly, the tools by which the constructs present in the study were measured were "self-report", which leads to the tendency of the participants to answer desirably to the questions. At the same time, another limit is imposed by measuring the constructs through a single evaluation method.

employee "citizenship." Academy of Management Journal, 26(4), 587-595.

Bennett, R. J., \& Robinson, S. L. (2000). Development of a Measure of Workplace Deviance. Journal of Applied Psychology, 85, 349-360. 
Borman, W. C., \& Brush, D. H. (1993). More Progress Toward a Taxonomy of Managerial Performance Requirements. Human Performance, 6(1), 1-21.

Borman, W. C., \& Motowidlo, S. J. 1997. Task performance and contextual performance: The meaning for personnel selection research. Human Performance, 10, $99-109$.

Borman, W. C., \& Motowidlo, S. J. 1993. Expanding the criterion domain to include elements of contextual performance. In N. Schmitt, W. C. Borman, \& Associates (Eds.), Personnel selection in organizations, 71-98. San Francisco, CA: Jossey-Bass.

Brackett, M., \& Mayer, J. D. (2003). Convergent, Discriminant, and Incremental Validity of Competing Measures of Emotional Intelligence. Personality and social psychology bulletin, 29(9), 1147-1158.

Brief, A. P., \& Motowidlo, S. J. (1986). Prosocial organizational behaviors. Academy of Management Review, 11, 710-725.

Campbell, J. P. (1990). Modeling the performance prediction problem in industrial and organizational psychology. In M. D. Dunnette \& L. M. Hough (Eds.), Handbook of Industrial and Organizational Psychology. Palo Alto, CA: Consulting Psychologists Press, Inc.

Campbell, J. P., McCloy, R. A., Oppler, S. H., \& Sager, C. E. (1993). A theory of performance. In N. Schmitt \& W. C. Borman (Eds.), Personnel selection in organizations (pp. 35-70). San Francisco: Jossey-Bass.

Carter, N. L., Guan, L., Maples, J. L., Williamson, R. L., \& Miller, J. D. (2015). The downsides of extreme conscientiousness for psychological wellbeing: The role of obsessive compulsive tendencies. Journal of Personality.

Chen, P., Spector, P.E. (1992). Relationship of work stressors with aggression, withdrawal, theft and substance use: An exploratory study. Journal of Occupational and Organizational Psychology, 65, 177-184.

Chiaburu, D. S., Oh, I.-S., Berry, C., Li, N., \& Gardner, R. G. (2011). The Five-Factor Model of Personality Traits and Organizational Citizenship Behaviors: A Meta-Analysis. Journal of Applied Psychology, 96(6), 1140-1166.

Colquitt, J. A. (2001). On the Dimensionality of Organizational Justice: A Construct Validation of a Measure. Journal of Applied Psychology, 86(3), 386-400.

Costa, P. T. \& McCrae, R. R. (1992). NEO personality Inventory professional manual. Odessa, FL: Psychological Assessment Resources.
Costa, P. T. Jr., \& McCrae, R. R. (1985). The NEO Personality Inventory Manual. Odessa, FL: Psychological Assessment Resources, Inc.

Costa, P. T., \& McCrae, R. R. (1976). Age differences in personality structure: A cluster analytic approach. Journal of Gerontology, 31(5), 564-570.

Costa, P. T., \& McCrae, R. R. (1992). Revised NEO Personality Inventory (NEO PI-R) and the NEO Five-Factor Inventory (NEO-FFI) Professional Manual. Odessa, FL: Psychological Assessment Resources.

Crant, J. M. (1995). The Proactive Personality Scale and objective job performance among real estate agents. Journal of Applied Psychology, 80, 532-537.

DeYoung, C., Peterson, J., \& Higgins, D. (2002). Higherorder factors of the Big Five predict conformity: Are there neuroses of health? Personality and Individual Differences, $33,533-552$.

Douglas, S. C., \& Martinko, M. J. (2001, September). Exploring the Role of Individual Differences in the Prediction of Workplace Aggression. Journal of Applied Psychology, 86(4):547-59.

Duckworth, A. L., Peterson, C., Matthews, M. D., \& Kelly, D. R. (2007). Grit: Perseverance and passion for long-term goals. Journal of Personality and Social Psychology, 9, 1087-1101.

Dudley, N. M., Orvis, K. A., Lebiecki, J. E., \& Cortina, J. M. (2006). A Meta-Analytic Investigation of Conscientiousness in the Prediction of Job Performance: Examining the Intercorrelations and the Incremental Validity of Narrow Traits. Journal of Applied Psychology, 91(1), 40-57.

Fox, S., Spector, P.E. (1999). A model of work frustrationaggression. Journal of Organizational Behavior, 20, 915931.

Fox, S., Spector, P.E., Miles, D. (2001). Counterproductive Work Behavior (CWB) in Response to Job Stressors and Organizational Justice: Some Mediator and Moderator Tests for Autonomy and Emotions. Journal of Vocational Behavior, 59, 291-309.

Frank L. Schmidt, J. E. Hunter (1998). The Validity and Utility of Selection Methods in Personnel Psychology: Practical and Theoretical Implications of 85 Years of Research Findings. Psychological Bulletin, 124(2), 262274.

Galperin, B. (2002). Determinants of deviance in the workplace. Teză doctorală nepublicată.

George, J. M., \& Brief, A. P. 1992. Feeling good-doing good: A conceptual analysis of the mood at work- 
organizational spontaneity relationship. Psychological Bulletin, 112, $310-329$.

George, J. M. 1990. Personality, affect, and behavior in groups. Journal of Applied Psychology, 75, 107-116.

George, J. M. 1991. State or trait: Effects of positive mood on prosocial behavior at work. Journal of Applied Psychology, 76, 299-307.

George, J. M., \& Bettenhausen, K. 1990. Understanding prosocial behavior, sales performance, and turnover: A group-level analysis in a service context. Journal of Applied Psychology, 75, 698 -709.

George, J. M., \& Jones, G. R. 1997. Organizational spontaneity in context. Human Performance, 10, 153-170.

Graziano W.G.; Bruce J. W.; Sheese B.E.; Tobin R.M. (2007). "Attraction, personality and prejudice: Liking none of the people most of the time". Journal of Personality \& Social Psychology, 93, 565-582.

Graziano, W.G., \& Eisenberg, N. (1997). Agreeableness; A dimension of personality. In R. Hogan, S. Briggs, \& J. Johnson, (1997). Handbook of Personality Psychology. San Diego, CA: Academic Press.

Iliescu, D., \& Ticulescu, L. (2014). Training APIO (Asociația de Psihologie Industrială și Organizațională). Retrieved from Diagnoza organizationala (nivel introductiv): http://training.apio.ro/.

Ivcevic, Z., \& Brackett, M. (2014). Predicting school success: Comparing Conscientiousness, Grit, and Emotion Regulation Ability. Journal of Research in Personality, 52, 29-36.

John, O. P., Naumann, L. P., \& Soto, C. J. (2008). Paradigm Shift to the Integrative Big-FiveTrait Taxonomy: History, Measurement, and Conceptual Issues. In O. P. John \& R. W. P. Robins, La As (Eds.), Handbook of personality: Theory and research (pp. 114-158). New York, NY: Guilford Press.

Katz D., \& Kahn R. L. (1966). The social psychology of organizations. New York: Wiley. p 489.

Katz, D. (1964). The motivational basis of organizational behavior. Behavioral Science 9, 131-133.

Laursen, B., Pulkkinen, L., Adams, R. (2002). The antecedents and correlates of agreeableness in adulthood. Journal of Developmental Psychology, 38(4), 591-603.

Lepine, J. A., Erez, A., \& Johnson, D. E. (2002). The nature and dimensionality of organizational citizenship behavior: a critical review and meta-analysis. Journal of Applied Psychology, 87(1), 52-65.
Matsumoto, D., \& Juang, L. (2012). Culture and Psychology: 5th Edition. Belmont, CA: WadsworthCengage Learning. p. 271.

Mayer, J. D., \& Salovey, P. (1997). What is emotional intelligence? In P. Salovey \& D. Sluyer (Eds.), Emotional development and emotional intelligence: Implications for educators (pp. 3-31). New York: Basic Boks.

Mayer, J. D., Roberts, R. D., \& Basarde, S. G. (2008). Human abilities: Emotional intelligence. Annual Review of Psychology, 59, 507-536.

Mayer, J. D., Salovey, P., Caruso, D. L., \& Sitarenios, G. (2001). Emotional intelligence as a standard intelligence. Emotion, 1, 232-242, 396.

Morrison, E. W., \& Phelps, C. C. (1999). Taking charge at work: Extrarole efforts to initiate workplace change. Academy of Management Journal, 42, 403- 419.

Motowidlo, S. J., \& Van Scotter, J. R. 1994. Evidence that task performance should be distinguished from contextual performance. Journal of Applied Psychology, 79, 475- 480.

Motowildo, S. J., Walter, C. B., \& Schmit, M. J. (1997). A Theory of Individual Differences in Task and Contextual Performance. Human Performance, 10(2), 71-83.

O'Reilly, C., \& Chatman, J. 1986. Organizational commitment and psychological attachment: The effects of compliance, identification and internalization on prosocial behavior. Journal of Applied Psychology, 71, 492- 499.

Organ, D. W. (1988). Organizational Citizenship behavior: The good soldier syndrome. Lexington, MA: Lexington Books.

Ozer, D. J., \& Benet-Martínez, V. (2006). Personality and the prediction of consequential outcomes. Annual Review of Psychology, 57, 401-421.

Pearson, C. M., \& Porath, C. L. (2005). On the nature, consequences and remedies of workplace incivility: No time for "nice"? Think again. Academy of Management Executive, 19(1).

Penney, L.M., Spector, P.E. (2002). Narcissism and counterproductive work behaviors: Do bigger egos mean bigger problems? International Journal of Selection and Assessment, 10(1/2), 126-134.

Pervin PhD, Lawrence A.; John PhD, Oliver P. (1999). Handbook of Personality: Theory and Research (2nd Edition). New York: Guilford Press. pp. 102-138.

Robinson, S.L., O'Leary-Kelly, A.M. (1998). Monkey see, monkey do: The influence of work groups on the antisocial 
behavior of employees. Academy of Management Journal, 41(6), 658-673.

Rimfeld, K., Kovas, Y., Dale, P. S., \& Plomin, R. (2016). True Grit and Genetics: Predicting Academic Achievement From Personality. Journal of Personality and Social Psychology.

Smith, A., Organ D. W., \& Near J. (1983). Organizational citizenship behavior: Its nature and antecedents. Journal of Applied Psychology, 68(4), 653-663.

Spector, P. E., \& Fox, S. (2005). The Stressor - Emotion Model of Counterproductive Work Behaviour. Washington, DC, USA: American Psychological Association. pp. 151174.

Spector, P. E., Fox, S., Penney, L. M., Bruursema, K., Goh, A., \& Kessler, S. (2006). The dimensionality of counterproductivity: Are all counterproductive behaviors created equal? Journal of Vocational Behavior, 68, 446460.

Sulea, C. (2008). Counterproductive behavior in organization. In E. Avram and C. Cooper (Eds.) Contemporary tendencies in Organizational - Managerial Psychology. Iași: Polirom.

Thompson, E.R. (2008). Development and Validation of an International English Big-Five Mini-Markers. Personality and Individual Differences, 45(6), 542-548.
Tsai, W.-C., Chen, C.-C., \& Liu, H.-I. (2007). Test of a Model Linking Employee Positive Moods and Task Performance. Journal of Applied Psychology, 92(6), 15701583.

Van Dyne, L., \& LePine, J. A. (1998). Helping and voice extra-role behaviors: Evidence of construct and predictive validity. Academy of Management Journal, 41, 108-119.

Van Dyne, L., Cummings, L. L., \& Parks, J. M. 1995. Extrarole behaviors: In pursuit of construct and definitional clarity (A bridge over muddied waters). Greenwich, CT: JAI Press.

Williams, K. D., \& Karau, S. (1991). Social Loafing and Social Compensation: The Effects of Expectations of CoWorker Performance. Journal of Personality and Social Psychology, 61(4), 570-581.

Williams, L., \& Anderson, S. (1991). Job Satisfaction and Organizational Commitment as Predictors of Organizational Citizenship and In-Role Behaviors. Journal of Management, 17(3), 601-617.

Wong, C.-S., \& Law, K. S. (2002). The effects of leader and follower emotional intelligence on performance and attitude: An exploratory study. The Leadership Quarterly, 13, 243-274. 